Hispania Sacra, Missionalia hispanica, 58 117, enero-junio 2006, 355-381, ISSN: 0018-215-X

\title{
PODER Y RELACIONES SOCIALES EN CURATOS DE INDIOS. EL CURATO DE COCHINOCA EN EL SIGLO XVIII (PUNA DE JUJUY-ARGENTINA)
}

\author{
POR \\ ENRIQUE NORMANDO CRUZ \\ Investigador Asistente del Consejo Nacional de Investigaciones Científicas y Técnicas. \\ República de Argentina
}

\begin{abstract}
RESUMEN
El ejercicio del poder religioso en curatos rurales de población mayoritariamente indígena, fue desarrollado en los distritos andinos del virreinato del Río de la Plata por los «curas doctrineros». Este trabajo pone en consideración la conjetura de que el ejercicio del poder de los curas doctrineros se desarrolla a partir de un «acuerdo de expropiación colonial» entre él mismo, las autoridades indígenas y los feligreses del curato. Para confrontarla se realiza una específica identificación de los partícipes del acuerdo: autoridades indígenas, curas doctrineros, auxiliares religiosos y encomenderos; y se describe el origen y desarrollo de las «tradiciones institucionalizadas» fruto de tal acuerdo: cofradías y obvenciones.
\end{abstract}

PALABRAS CLAVE: Curas doctrineros, gobernadores y caciques indígenas, cofradías, obvencionales, Cochinota

\begin{abstract}
The exercise of the religious power in rural pastorates of mainly native population, was developed in the Andean districts of the viceroyalty of the River of the Silver by the «you cure doctrineros». This work puts in consideration the conjecture that the exercise of the power of them you cure doctrineros develops from an «agreement of colonial expropriation» among he himself, the native authorities and the parishioners of the pastorate. Confronting it a specific identification of the participants of the agreement is carried out: native authorities, priests doctrineros, you help religious and grocers; and the origin is described and development of those of traditions institutionalized» fruit of such agreement: brotherhoods and bonuses.
\end{abstract}


KEY WORDS: You cure doctrineros, governing and native overlords, brotherhoods, bonuses, Cochinoca

\section{INTRODUCCIÓN}

El ejercicio del poder religioso en curatos rurales de población mayoritariamente indígena, fue desarrollado en los distritos andinos del virreinato del Río de la Plata por los «curas doctrineros». Este trabajo pone en consideración la conjetura de que el ejercicio del poder de los curas doctrineros se desarrolla a partir de un «acuerdo de expropiación colonial» entre él mismo, las autoridades indígenas y los feligreses del curato. Para confrontar dicha conjetura, se realiza una específica identificación de los partícipes del acuerdo: autoridades indígenas, curas doctrineros, auxiliares indígenas del doctrinero, encomenderos y otros; y se describe el origen y desarrollo de lo que denomino las «tradiciones institucionalizadas» fruto de tal acuerdo: las cofradías y los obvencionales religiosos.

El estudio se enfoca en revisar la actuación de dos curas doctrineros en el curato de Cochinoca, una jurisdicción eclesiástica del distrito de Jujuy vecino a los distritos mineros de la Audiencia de Charcas y al norte de lo que luego será a fines del XVIII el virreinato del Río de la Plata. Tomando en cuenta como referencia teórica la más que importante bibliografía que sobre el ejercicio doctrinal existe para el resto de Hispanoamérica ${ }^{1}$.

En cuanto a las fuentes, se trabajó especialmente con dos expedientes judiciales depositados en el Archivo del Obispado de Jujuy, elaborados por las au-

\footnotetext{
1 En la búsqueda empírica y en algunos de los análisis realizados, el trabajo que ha servido de referencia es un artículo que analiza una muestra de varias decenas de juicios a curas doctrineros en el virreinato del Perú a mediados del XVII; en el que se señala los principales rasgos económicos y políticos de su actuación en doctrinas de indios, y las instituciones desarrolladas en la relación comunidades indígenas, autoridades eclesiásticas y mercado (Acosta, 1982). Para el mismo espacio peruano, también se ha revisado que la actuación de los clérigos en doctrinas de indios, corresponde a la explotación en el marco de la sumisión y la derrota indígena (Lavallè, 1982); y descrito muy bien el rol del poder eclesiástico del cura doctrinero en el marco de la economía mercantil (Pons Pons, 1990). Así como los medios del ejercicio de ese poder, de gobierno e intermediación entre las comunidades y las otras autoridades hispánicas (Sala i Vila, 1993 y 1994). Para Nueva España, los estudios sobre el clero secular en doctrinas de indios son tan valiosos como los que hay para el espacio Peruano. Así se cuenta con análisis de los procesos de secularización, del pasaje del control y gobierno colonial del clero regular al secular, del ejercicio de la jurisdicción eclesiásticas en las comunidades indígenas, y del control del cura de una parte de los excedentes comunitarios (Brading, 1994). También de análisis del rol de los curas y las instituciones eclesiásticas en los procesos étnicos al interior y en relación con la sociedad toda de las comunidades indígenas (Carmagnani, 1993). Otros trabajos menos precisos en el estudio de los curas en doctrinas de indios, son los que caracterizan los medios de control religioso y el rol del cura doctrinero en el gobierno colonial (Gibson, 1986), y los procesos de sincretismo y aculturación religiosa de las sociedades indígenas para dar lugar a «culturas nuevas» en las que los curas doctrineros tienen un nuevo e importante lugar (Gruzinsky, 1995).
}

Hispania Sacra, Missionalia hispanica, 58

117, enero-junio 2006, 355-381, ISSN: 0018-215-X 
toridades superiores de los curas doctrineros. Que corresponde el primero a un juicio sustanciado por la Visita del obispo del Tucumán en 1735, al cura doctrinero por «maltratos a la autoridad civil indígena y cobro indebido de obvencionales»; y el segundo, refiere a 1803 sobre una actuación de oficio desde el curato rectoral de Jujuy contra el cura doctrinero por «desarreglo de vida y malas costumbres». Documentos que se complementaron con los «Libros de fábrica» del curato en cuestión ${ }^{2}$ y referencias sobre el pago del sínodo a los doctrineros.

Los casos a los que refieren los dos juicios, se desarrollan en la misma sede del curato: el pueblo indígena de Cochinoca, que es el que da el nombre al curato y han sido seleccionados de un conjunto de juicios contra curas doctrineros en el período colonial ${ }^{3}$, porque son los que de manera más clara nos permiten identificar a los actores sociales, su rol y el carácter de la dominación y las instituciones y tradiciones construidas en el marco del acuerdo de expropiación colonial.

\section{El curato de Cochinoca en la Puna de Jujuy en el siglo XVIII (ARGENTINA)}

El distrito colonial de Jujuy está ubicado en el medio de los caminos que permiten la circulación mercantil en un gran espacio que vincula regionalmente las ciudades del antiguo Tucumán Colonial (Salta, Tucumán, Santiago del Este-

\footnotetext{
${ }^{2}$ Los «Libros de fábrica» son los libros que elaboran los curas doctrineros referentes a la construcción, reparación, mantenimiento y ornamentación de los templos de las iglesias a su cargo, y también del registro y administración de los bienes afectados a favor de la Iglesia. En este caso tratase de los libros de las parroquias de Casabindo, de Cochinoca y del anexo de Moreno de 1798 a 1826 depositados en el Archivo Histórico de la Provincia de Jujuy.

3 De manera extraña la historiografía Argentina no se ha detenido en la búsqueda y análisis de juicios contra curas doctrineros. Para el distrito de Jujuy en todo el período colonial (de 1593 a la crisis independentista de la segunda década hasta mediados del XIX), sólo se cuenta con dos estudios específicos sobre el clero secular en curatos de indios. Uno que describe en general el curato rural de Humahuaca (Sánchez Matamoros, 2004) y otro que analiza las cofradías religiosas como una institucionalización de coerción económica y extraeconómica y de desarrollo de estrategias de resistencia y lucha contra ellas (Cruz, 2001). A nivel regional, solo se cuenta con un trabajo sobre el clero colonial de Salta a fines del período, que estudia la ordenación y la composición social del clero secular y la conflictiva relación que establece el «viejo» clero con el «nuevo» en la ruptura del orden colonial (Caretta de Gaufin, 1999). Sin desarrollar específicamente la actuación del clero doctrinero en curatos de indios. De manera similar, para el distrito de Córdoba, se han descrito las representaciones sociales del clero, entre la Iglesia colonial y la surgida de la Independencia, y examinado la cuestión de los concursos y de la escasez real del clero (Ayrolo, 2000 y 2001). Problemas modernos del clero colonial, pero de poca representatividad empírica para el período colonial y especialmente en curatos rurales de indios, tal cual es la situación de muchos distritos al norte del Río de la Plata
} 
ro y Catamarca), con los espacios ganaderos del Litoral argentino y los mercados Potosinos (Assadourian, 1983) ${ }^{4}$.

Además de contar con esta particularidad regional dentro de los circuitos mercantiles $^{5}$, la ciudad de Jujuy es de todos los distritos del Río de la Plata en el siglo XVIII, el que mayor cantidad de población indígena tiene respecto de la población blanca española y negra esclava o libre. Pues Córdoba, que es la capital civil de la gobernación hasta la división y reorganización administrativa en Intendencias, registra porcentualmente un $10 \%$ de indios, y el distrito más cercano en dicha población a Jujuy: Santiago del Estero (la sede del Obispado hasta la creación de la Intendencia de Salta del Tucumán) tiene un 32\%, mientras que Jujuy registra un lejano $82 \%$ de población indígena (Maeder, 1984: 10).

La distribución y ordenamiento del ejercicio de la evangelización, de los deberes políticos, de las funciones públicas y de los servicios administrativos que corresponden al distrito de Jujuy, se organiza en torno a los curatos. Circunscripción de tipo eclesiástica que tiene su origen en la doctrina de indios tributarios y que, reconocida por el Estado colonial, divide en el siglo XVIII el gobierno de todos los territorios que comprende la jurisdicción.

Para el año de 1735, todo el distrito de Jujuy esta dividido en tres curatos: el rectoral de Jujuy, el de Humahuaca y el de Cochinoca; y en 1803 se divide en nueve: Rectoral, Tumbaya, Humahuaca, Casabindo y Cochinoca, Santa Catalina, Yavi, Rinconada, Perico y Río Negro ${ }^{6}$. El curato de Cochinoca (y en 1803 también los de Santa Catalina, Yavi y Rinconada) corresponde en su jurisdicción al espacio que se conoce como la «Puna de Jujuy», referencia local y regional que alude a un espacio mayor que abarca parte de los distritos vecinos de Salta y Catamarca, Puna de Atacama y el Sur de Charcas.

\section{LOS CURAS DOCTRINEROS DE COCHINOCA}

La precisión del ejercicio del poder de los curas doctrineros y la identificación de los actores sociales y de las instituciones del «acuerdo de expropiación colonial» se realizará en el análisis de dos juicios. El primero trata de la visita

\footnotetext{
4 Ver Anexo. Mapa 1. Jujuy en la circulación mercantil regional. Elaborado en base a Moutoukias (1988). Esta configuración del espacio económico regional se desarrolla con plenitud en el siglo XVIII, y corresponde históricamente al período que va desde su segunda mitad hasta la crisis de la Independencia, pasando por las reformas borbónicas.

5 El período de análisis de este estudio, se incluye en el pleno desarrollo del mercantilismo en la región: desde fines de XVII hasta la crisis de la Independencia (primera década hasta mediados del XIX) (Santamaría, 1999).

6 Ver en Anexo Mapa 2. Curatos de Jujuy: 1735-1803.
}

Hispania Sacra, Missionalia hispanica, 58

117, enero-junio 2006, 355-381, ISSN: 0018-215-X 
del obispo José de Cevallos a los curatos del distrito de Jujuy en $1735^{7}$, que da lugar en su registro y control del curato de Cochinoca, a un expediente contra el cura interino Valentín Albornoz Ladrón de Guevara, por el cobro indebido de obvencionales religiosos y por maltratos al gobernador indígena. El segundo, es el expediente elaborado por el cura excusador Juan Ignacio Gorriti del curato de Jujuy, al cura de Casabindo y Cochinoca Manuel Benito Arias por «desarreglo de vida y malas costumbres» de 1803.

En la sede del curato de Cochinoca: el pueblo de Cochinoca, y en el marco de la visita que realiza a la diócesis del Tucumán el obispo José Antonio Gutiérrez de Cevallos y sus colaboradores, se elabora un expediente y se sustancia un juicio por la denuncia que realiza el gobernador del pueblo indígena de Cochinoca Fernando Bilti ${ }^{8}$. En la que expresa que el cura interino Valentín Albornoz Ladrón de Guevara, lo maltrató y arrastró junto a la iglesia y le arrancó dos pedazos de cabello de la cabeza. Que la agresión se desarrolló luego de una discusión que el gobernador indígena tuvo con el cura, porque supuestamente se había negado o mostrado renuente a prestarle unos servicios que le había solicitado.

Como consecuencia de las averiguaciones que se realizan para determinar el valor de la denuncia del gobernador indígena, salen a luz otras imputaciones contra el cura doctrinero: que se apropia y usa para sus fines particulares los bienes de las cofradías y de las fiestas religiosas, que cobra obvencionales que no corresponden a los indígenas tributarios, que no aplica a la «fabrica de la iglesia» los bienes que recibe como pago por servicios eclesiásticos, que no le paga a las mujeres indígenas que tiene trabajando para él, que no brinda los servicios religiosos de «distinción» que corresponde a las autoridades indígenas, y finalmente, que por la exigencia de trabajar para él en los arreos de ganado y por el maltrato en la catequesis, los jóvenes indígenas se fugan del curato.

Luego de tomadas las primeras declaraciones de testigos indígenas, que confirman en parte la acusación de la que partió el juicio, el gobernador indígena se va a retractar, sin embargo, la visita del obispado continua de oficio con el juicio, y le toma declaración al cura y elabora una nueva serie de interrogacio-

\footnotetext{
7 Las visitas pastorales se consideran de vital importancia para el funcionamiento de una diócesis, pues pone en contacto a las iglesias particulares con el obispo, ultimo responsable de ellas. El contenido y las formas están delimitadas por el Concilio de Trento, el derecho canónico, las cedulas reales, los concilios y sínodos Americanos y en ultimo caso, por el mismo obispo (García Añoveros, 1990). Para el obispado del Tucumán las visitas debían ser preparadas por el cura por donde pasase el obispo o visitador, disponiendo a los feligreses para los sacramentos de la penitencia y confirmación (Bruno, 1968).

8 «Causa criminal contra el cura de Cochinoca Maestro Don Valentín Albornoz Ladrón de Guevara, Cochinoca, año 1735». Archivo del Obispado de Jujuy (en adelante AOJ), Caja 8, Legajo 15 (documento 653 y 656).
} 
nes pero esta vez dirigidas no solo a probar el supuesto maltrato inicial del que parte el juicio, sino esta vez, todo el desempeño general del cura en su ejercicio, especialmente en lo atinente al cobro indebido de aranceles, al trabajo compulsivo e indebido, y a la apropiación particular de los bienes de la iglesia que debe tener solo a su cuidado y administración.

Por eso el cura doctrinero presenta un arancel de obvencionales de autoría local de Jujuy, con el que se manejaba en el cobro de los servicios religiosos que le imputan como indebidos. Y dado que ahora el juicio corresponde principalmente a esta cuestión, el gobernador indígena también presenta a la visita otro arancel, copia de uno emanado del obispado de Charcas.

Llama la atención que la visita haya resuelto no sólo la culpabilidad general del cura doctrinero, sino que específicamente elige como arancel de vigencia y legalidad el que presenta el gobernador indígena. Tal vez esta decisión de la superioridad eclesiástica, tuviera que ver con el hecho de que el arancel presentado por el gobernador indígena es del Arzobispado de Charcas, mientras que el presentado por el doctrinero es una copia del cura del rectoral del distrito, o bien porque hay que creerle al aire general del obispado del Tucumán que considera durante todo el siglo XVIII que las visitas son para poner orden: «Allí mismo comenzó la visita general para la reforma de sus abusos y establecimiento de sólidos preceptos, que conduzcan a la edificación de los fieles, a la disciplina eclesiástica y al servicio de Vuestra Majestad» ${ }^{9}$. Pues, y en esto es consonante con las autoridades civiles, se considera que: «Con excepción de unos pocos en todos los de más clérigos (dice el gobernador Campero) no reconozco los meritos para ser promovidos de sus curatos y capellanías a sus beneficios; y hay muchos sediciosos, ignorantes y relajados, particularmente en comercios, que va poniendo en orden el señor obispo doctor don Juan Manuel Abad Illana» (Bruno, 1968: 460).

Lo concreto es que no sólo no se admite el arancel presentado por el doctrinero, sino que también se condena al cura por las primeras acusaciones del gobernador indígena de maltrato, y también, por las acusaciones generales determinadas de oficio por la visita. Específicamente se lo condena por el maltrato excesivo al cacique y gobernador indígena de forma pública, por la apropiación y uso indebido de los bienes de las cofradías religiosas, por el cobro indebido de obvenciones a los tributarios, por el trabajo gratuito que impone a las indias de su curato, por el rigor en el trato de los más jóvenes en la catequesis, por la no concurrencia a las confesiones o servicios generales a las autoridades indígenas del curato y finalmente por la exigencia indebida de servicios y bienes al gobernador y cacique indígena.

\footnotetext{
9 Así lo declara el obispo Moscoso y Peralta en su toma de cargo y posesión y visita a Jujuy a mediados de 1773. (Bruno, 1968: 499).

Hispania Sacra, Missionalia hispanica, 58

117, enero-junio 2006, 355-381, ISSN: 0018-215-X
} 
De esta manera para estos años del siglo XVIII en que está plenamente configurado la estructura de dominación colonial, para que se invalidara y cuestionara la autoridad del cura doctrinero ante la feligresía indígena y el gobernador y cacique, es necesario que además de probarse el ejercicio ilegal de violencia y maltratos a la autoridad indígena ${ }^{10}$, se sumarán y probarán otros abusos y delitos, como puede ser el cobro indebido de obvencionales, la imposición de trabajo gratuito y la apropiación particular del cura doctrinero de recursos de uso público para la evangelización.

En la misma cabecera del pueblo de Cochinoca, pero esta vez en el particionado curato de Casabindo y Cochinoca ${ }^{11}$, el 4 de febrero de 1803 el cura del rectoral de Jujuy Juan Ignacio de Gorriti, como cura excusador del curato de Casabindo y Cochinoca, realiza las averiguaciones correspondientes a una serie de acusaciones contra el cura doctrinero Manuel Benito Arias sobre su conducta pública por «desarreglo de vida y costumbres» ${ }^{12}$.

La actuación judicial del excusador enviado desde Jujuy, se inicia porque al parecer llega a oídos de las autoridades superiores del curato rectoral, que el cura Arias tiene «trato ilícito y escandaloso» con una feligrés, como se llama a las relaciones sexuales prohibidas y desarrolladas públicamente, es decir con conocimiento de causa de la República. Pero a la luz de los testimonios, se amplia la actuación del la superioridad eclesiástica a la figura de «desarreglos de vida y costumbres», dado que de acuerdo a distintos testimonios, el cura Arias tenía más bien «trato familiar e ilícito» con dos hermanas españolas, una de las cuales había tenido dos hijos con él, y que los había mandado a vivir fuera del curato al distrito de Salta y a la ciudad de Jujuy. Pero además, y para agravar es-

10 Tal como sucede por ejemplo en 1660 en la sierra norte de Lima, cuando el curaca de Ambar demanda al sacerdote porque le quito el sombrero de la cabeza y lo arrojó al suelo, además de insultarlo y llamarlo perro borracho, amenazándolo con darle de mil palos y expulsarlo del pueblo. Para el curaca Juan Rodríguez Pilco, las actitudes del doctor Diego de Alva representan un terrible insulto hacia su persona: «porque siendo cacique principal y gobernador y persona notable me trató como a plebeyo afrentándome con palabras tan infames y graves en que nunca e incorrido porque soy muy sobrio y procedo ajustadamente y si por cedula de Su Majestad tiene encargada que las injurias y delitos cometidos contra los yndios se castiguen con mayor demostración que si fuesen hechos de español a español no ay duda que si el que lo fuese quitarse a otros español el sombrero de la cabeza y lo tirase al suelo y lo dirigiese dichas palabras le tendría por otra injuria con mas fuerza se a de tener la hecha contra un cacique cuando su Majestad encarga tanto su buen tratamiento...» Archivo Arquidiócesis de Lima Cap. Leg. 17. exp. 15 ff. 41-41 v. Citado por Monsalve Zanatti, 1998: 385-386.

11 Hasta 1756 el curato de Cochinoca comprende los pueblos indígenas de Río de San Juan, Valle Rico de la Rinconada, Yavi, Casabindo, Cochinoca y Santa Catalina. Desde ese año pierde los parajes y pueblos que se agrupan en el curato de Santa Catalina; y luego en 1773 los territorios que conforman los curatos de San Francisco de Yavi y de Rinconada. Por lo que para 1803 se conoce a este curato como de Casabindo y Cochinoca, porque comprende principalmente los parajes, pueblos, potreros y rodeos situados entre estos dos pueblos. Ver Anexo Mapa 2. Curatos de Jujuy: 1735-1803.

12 «Causa criminal contra el cura de Cochinoca Manuel Benito Arias por desarreglo de vida y malas costumbres, Cochinoca, 6 de septiembre de 1803», AOJ, Caja 1, Legajo 12. 
tas acusaciones, Arias también «tenía amistad» con otras dos hermanas, al parecer también españolas, y una de ellas casada con su mayordomo de iglesia un tal «Valenciano.

La «amistad ilícita» era el término común del discurso oficial para designar los cuatro delitos condenados por ambos derechos, el civil y el canónico: la fornicación o relación sexual prematrimonial, el concubinato o amancebamiento, el adulterio y el incesto. Específicamente de ninguno de estos delitos es reputado Arias, pero si de una combinación de ellos con la idea de paternidad sobre la feligresía indígena que ejerce del cura o «padre»: «trato familiar e ilícito» y «amistad» ${ }^{13}$.

El problema para Arias, parece derivar del «trato familiar e ilícito» o de las «amistades», aunque las mismas autoridades parecen reconocer la costumbre de la conciencia campesina indígena de que la simple fornicación no constituye ni delito ni pecado, al caratular la causa como de «desarreglo de vida y costumbres». Y también del hecho de que todas estas relaciones entre el cura y las cuatro hermanas, habían dado lugar a disputas violentas y públicas entre las cuatro mujeres, intermediadas por las autoridades indígenas, los colaboradores del cura y las autoridades delegadas de la ciudad de Jujuy, como el subdelegado de la Puna que ante los desordenes públicos ocasionados por la disputa entre las cuatro mujeres, destierra a dos de las hermanas fuera del curato.

De esta manera el problema de las autoridades, y lo que lleva a que actúen prácticamente de oficio y hagan renunciar al cura doctrinero al curato a pesar de que resultaba un muy buen administrador, como se verá más adelante, es que al reconocerse la fornicación del cura se anulaba de alguna manera la reinvindicación de utilizar el matrimonio como un recurso contra la fornicación, aspecto tan caro al cristianismo desde la Edad Media y revalorizado de nuevo en esta parte andina de las Indias por la renuencia indígena al matrimonio y la práctica del «amancebamiento», o como se denominado con sus referencias locales: «amasio», «amañamiento» y «sirviñaco». Además, el mismo reconocimiento de fornicación atentaba contra la autoridad eclesiástica del doctrinero, pues invalidaba «las exigencias lacias que no admitían que el sacerdote el que consagra la ostia estuviese en posesión de una mujer, que sus manos consagradoras estuviesen manchadas de lo mas claramente alejado de lo sagrado ${ }^{14}$.

13 En especial la Iglesia Indiana a través de la Inquisición se preocupó por los blasfemos, las hechiceras, los que incurrían en los delitos de la «amistad ilícita» y en el caso de los religiosos del delito de la «solicitud» (Millar Carvacho, 1997). Pero no directamente de las situaciones derivadas del caso que estamos analizando: «desarreglo de vida y costumbres».

${ }^{14}$ Ideas surgidas del movimiento de purificación europeo de alrededor de 1130, que ya previamente había logrado la prohibición del matrimonio para los eclesiásticos alrededor del 1100 (Duby, 1991: 26).

Hispania Sacra, Missionalia hispanica, 58

117, enero-junio 2006, 355-381, ISSN: 0018-215-X 


\section{PODER Y RELACIONES SOCIALES}

El poder puede ser considerado en general, como «la capacidad de asegurarse el cumplimiento de obligaciones por parte de las unidades de un sistema de organización colectiva, en el cual las obligaciones son legitimadas en base a su relevancia para el logro de objetivos colectivos, y en el que, en caso de negativa, existe una expectativa de imposición de sanciones negativas, sea cual fuere el sujeto que dispone concretamente tal imposición" (Parsons, 1991: 64). Considero que las unidades del sistema de organización colectiva vigentes durante el período colonial, en las que pueden estudiarse las relaciones de poder en los curatos rurales indígenas, son primero los actores que viven la relación social del poder, y segundo, las tradiciones e instituciones de desarrollo de dichas relaciones sociales.

Por ello es que para analizar el tipo y marco del ejercicio del poder y las relaciones sociales derivadas del mismo al interior de los curatos rurales indígenas, es que a continuación se identificaran los actores sociales y luego se describirán las tradiciones e instituciones.

\subsection{Los actores}

En cuanto a los actores sociales, se identificó que el primer actor es el cura doctrinero. En esta parte Sur de la Audiencia de Charcas y luego Norte del virreinato del Río de la Plata, y durante todo el siglo XVII, los curas doctrineros son los curas encargados, por las autoridades seculares de cada rectoral o del obispado, de atender la doctrina de los indios tributarios. Pero al decaer, especialmente en la segunda mitad del siglo XVIII, el número de tributarios (sobretodo de los encomendados a particulares), y a aumentar el número de forasteros o foráneos y también, al cambiar las relaciones sociales de producción de los mismos tributarios con los encomenderos ${ }^{15}$; se constituyeron en torno a los espacios que correspondían a las doctrinas de indios, «curatos» de difícil precisión étnica, social y económica y con funciones más amplias que la «doctrina» de los indios. Por lo que el cura doctrinero pasa a ser el responsable de la evangelización y el gobierno eclesiástico general de toda la feligresía de una circunscripción, que si bien se había originado de una encomienda, ahora resultaba en una delimitación espacial y de gobierno más vinculada al cabildo de la ciudad $^{16}$.

15 Este importante proceso que transformó la estructura poblacional y social de toda Hispanoamérica, se ha considerado historiográficamente en torno a las relaciones de las sociedades indígenas con el mercado (Harris, Larson y Tandeter, 1987), y también con el Estado (Morner, 1999).

${ }^{16}$ De esta manera en el siglo XVIII la división administrativa entre curatos para los indios no en- 
Esto en cuanto al significado jurisdiccional que tiene para el siglo XVIII el cargo de cura doctrinero, en cuanto al contenido y características del cargo, se ha enfocado su identificación a partir de la división de su ejercicio entre sus derechos y obligaciones, pues considero que la mejor manera de apreciar como se desarrollo la relación social del poder, es a través de la descripción de lo que puede y debe hacer cada actor social.

Entre los derechos que tiene el cura doctrinero encontramos:

- Puede disponer y contar con, por lo menos, dos indios como colaboradores directos. Son los llamados en estas regiones «pongos», indios que puede destinar para su servicio personal y especialmente para su servicio en general como evangelizador. La costumbre regional en los Andes es que los «pongos» se ocupan especialmente en el «arreo»y transporte de productos. Dado el importante desarrollo del mercantilismo que este espacio tiene en el siglo XVIII, la ubicación del distrito en general y del curato en particular en las vías comerciales, y cierto rol mercantil no del todo precisado de los curas doctrineros, el derecho a disponer de «pongos» es muy importante y valioso.

- Tiene el derecho a disponer de uno o más colaboradores indígenas para organizar y desarrollar el culto religioso, la catequesis y le evangelización en general. La cantidad de colaboradores que los feligreses indígenas le ceden debe ser suficientes para cubrir todos o por lo menos la mayoría de los siguientes oficios eclesiásticos: sacristanes, maestros de música, campaneros y maestros de letras. Algunos de ellos reciben un pago por el oficio específico que ejerce, costo que puede compartir con los feligreses o las autoridades civiles o eclesiásticas; mientras que otros son mantenidos por el doctrinero pero sin recibir un salario específico.

- Recibe un pago específico por los servicios eclesiásticos y la evangelización en general que brinda a los indígenas tributarios que viven y residen en el curato. En el caso de los tributarios encomendados a un español, para el siglo XVIII se trata de un pago de doce reales anuales y a en algunos casos productos para el culto en general ${ }^{17}$.

comendados y las doctrinas para los encomendados, pierde sentido por la transformación de muchas doctrinas en pueblos de indios y la llegada masiva de foráneos a las doctrinas que disminuye el peso relativo de originarios, en un proceso similar al que vive el Alto Perú desde fines del XVII (Saignes, 1991).

17 Por ejemplo el marqués de Tojo (encomendero con jurisdicción sobre gran parte de los indios del curato de Cochinoca desde el siglo XVII al XIX) suele pagar al cura doctrinero por cada uno de sus indios encomendados doce reales además de entregarle cera y vino en cada año (Madrazo, 1982: 111). En el curato vecino de Humahuaca el monto del pago es el mismo y no incluye productos. «Juicio de cobro de las tazas de los indios de la encomienda de indios de Humahuaca y Uquía por José Domínguez, Humahuaca-Jujuy, 1767», Archivo de Tribunales de Jujuy, Carpeta 44, Legajo 1469.

Hispania Sacra, Missionalia hispanica, 58

117, enero-junio 2006, 355-381, ISSN: 0018-215-X 
- Dispone y administra las limosnas recolectadas durante los oficios religiosos realizados para las advocaciones, fiestas y cofradías. La advocación religiosa es el culto y celebración relativamente familiar que comprende por lo menos una celebración religiosa anual. En cambio las fiestas y las cofradías religiosas, que también tienen su propia advocación, son más amplias socialmente, y dan lugar a la conformación de un cuerpo de autoridades y de fondos específicos para la realización de la fiesta y la celebración religiosas, a veces muchas al año (Diez Hurtado, 1994; Cruz, 2005).

- Tiene el derecho a percibir como parte de su salario como cura doctrinero, los obvencionales religiosos establecidos por la costumbre y la ley. Los obvencionales son el pago por todo tipo de servicio religioso realizado por el cura doctrinero de las prácticas sacralizadas de su feligresía.

- Es el encargado de administrar la «fábrica» de las iglesias a su cargo dentro del curato. Correspondiendo la «fábrica» el cuidado y la ornamentación de los templos; la compra, cuidado y administración de los elementos para el culto; el cuidado, refacción y construcción de los edificios eclesiásticos; y los bienes muebles o inmuebles afectados religiosamente como donaciones, limosnas o censos.

- Puede administrar de manera directa o indirecta los bienes muebles e inmuebles de las cofradías y fiestas religiosas, junto a las autoridades específicas de las fiestas y cofradías, y también en conjunto a veces con las autoridades indígenas del curato.

- Dispone de una parte del trabajo de la doctrina y de los feligreses indígenas en general a su cargo evangélico y de gobierno. Especialmente puede disponer del trabajo de mujeres para la ornamentación y mantenimiento del templo sede de su doctrina y evangelio, y para la atención y cuidado de su persona y para el desarrollo del culto en general. Así como disponer para similares del trabajo de los jóvenes indígenas que asisten al catecismo.

Entre las obligaciones que tiene el cura doctrinero encontramos:

- Debe usar a su arbitrio de los «pongos», pero de manera exclusiva para el transporte y «arreo» de productos que tengan que ver con el servicio específico de su tarea evangélica. Nunca para su servicio personal.

- No debe delegar en más de lo que corresponde en sus colaboradores indígenas: sacristanes y campaneros; la realización y el auxilio de sus tareas específicas de bautizar, casar y enterrar a sus feligreses. Y sobre todo debe realizar, exclusivamente él, el sacramento de la misa. 
- Sólo debe percibir como pago extra de los servicios religiosos que presta a los indígenas tributarios, únicamente lo que no corresponde por el pago que ya recibe por ellos en el llamado sínodo.

- De las limosnas recolectadas durante las fiestas generales y de las cofradías religiosas, puede disponer solamente lo que le corresponde por los servicios religiosos prestados durante las fiestas, y por las funciones religiosas específicas realizadas a favor de las cofradías (sepulturas y entierros).

- Debe desarrollar el catecismo y la evangelización ciñéndose a los obvencionales reconocidos por una autoridad superior, y haciendo prevalecer los obvencionales determinados por ley, respecto de los determinados por las costumbres locales.

- Debe administrar los bienes muebles e inmuebles de las «fábricas» de las iglesias a su cargo, exclusivamente para ese destino.

- Tiene que administrar los bienes muebles e inmuebles de las cofradías y fiestas religiosas, con sus autoridades específicas y llegado el caso y si fuere la costumbre, con las otras autoridades indígenas, pero para el «mantenimiento y fomento» exclusivo de dichas asociaciones.

- La tarea de disponer del trabajo de la doctrina y curato a su cargo, para el desarrollo en general y exclusivo de la evangelización. En el caso de tener que contar y contratar a mujeres indígenas para su servicio personal, estas deben ser «viejas», y llegado el caso de precisar de otras mujeres para prestar servicios o de trabajar específicamente en alguna tarea vinculada a la promoción y desarrollo de la evangelización, debe partir de su consentimiento libre, pagándoles el salario correspondiente a la tarea realizada. En el caso de los jóvenes varones que asisten al catecismo, si necesita y requiere de su trabajo, debe pagarles el salario correspondiente a la tarea encomendada y contar con su consentimiento. Además ha de tratarlos con consideración y sin rigor ni violencia ${ }^{18}$.

- Tratar a las autoridades indígenas como «señores de indios», es decir con consideración y trato público respetuoso. Pero haciéndoles también cargo de las responsabilidades religiosas de los indios a su cargo.

18 Estas recomendaciones tienen que ver con lo que parece ser una costumbre regional que los curas doctrineros «Para llevar a cabo sus actividades productivas, que podían estar muy diversificadas, el cura se servía de mano de obra indígena valiéndose para beneficiarse de ella de su posición preeminente en la comunidad. No sólo utilizaba los servicios personales de sus feligreses en las labores agrícolas sino que las extendía a una variada gama de actividades según conviniera como la manufactura textil, el pastoreo o los trabajos artesanales y de transporte. En general eran remunerados con sueldos por debajo de los normales, que en ocasiones servían para pagar el tributo» (Sala i Vila, 1993: 146).

Hispania Sacra, Missionalia hispanica, 58

117, enero-junio 2006, 355-381, ISSN: 0018-215-X 
- Catequizar a los indígenas jóvenes y aplicar el rigor y la fuerza que corresponda, pero de forma moderada, lo mismo que en general en su ejercicio religioso en el desarrollo evangélico con sus feligreses indígenas.

El otro actor importante en las relaciones sociales en los curatos indígenas son las autoridades indígenas y los auxiliares del cura doctrinero. Al respecto el cuadro de autoridades políticas de los pueblos de la Puna de Jujuy parece responder en alguna medida al patrón andino del cabildo de indios, pero esto sólo parcialmente, en tanto la estabilidad institucional parece ser menor, lo mismo que las vinculaciones de parentesco en su designación. No sucede lo mismo con el cuadro de otras autoridades de fiestas o las autoridades de cofradías religiosas, y entre los auxiliares de los curas doctrineros, en los cuales parece existir una mayor variedad y continuidad en el ejercicio de la autoridad.

Como ejemplo comparativo, y una de las pocas referencias locales con que se cuenta hasta el momento, en el vecino curato de Humahuaca se registra para el mismo período en que se desarrollan estos juicios las siguientes autoridades:

- Autoridades indígenas: Gobernador (sin el agregado de cacique); Segunda; Alcalde (dos o uno); Alférez y Alguacil ( 1 o 2);

- y como auxiliares del cura: Sacristán (de 1 a 3); Maestro de Capilla y Maestro de Canto ${ }^{19}$.

En el curato de Cochinoca, el cargo de gobernador indígena tiene el agregado de «cacique» ${ }^{20}$, y lo acompaña un «Segunda», autoridad que está a la par casi del gobernador. Junto a ellos tenemos dos alcaldes: un alcalde mayor y un alcalde ordinario de ley. El gobernador y cacique y el «segunda», se presentan como los máximas autoridades indígenas pero en concierto con los dos alcaldes, que se constituyen como su cuerpo consultivo y llegado el caso de reemplazo.

El gobernador y cacique principal es el máximo responsable del pueblo de indios ante el cura doctrinero, como tal, está a cargo de proveer y designar a los dos «pongos», de avalar la selección y aprovechamiento que el cura hace de sus auxiliares indígenas para el culto y evangelio, de promover y conseguir la asistencia y participación al catecismo de los varones jóvenes, de permitir el uso de mujeres de parte del cura en el servicio de asistencia religiosa a la iglesia, de

19 Autoridades indígenas de Humahuaca de 1735 a 1792 (Sánchez Matamoros, 2004: 30-34).

20 «De acuerdo a la legislación colonial, los caciques recibieron los títulos de gobernadores o principales, no estaban obligados a tributar, se les pagaba un salario proveniente del tributo de los otros indios y el cargo se heredaba del padre al primogénito. A cambio de estos privilegios estaban obligados a cobrar los tributos y llevarlos al corregidor, organizar las mitas y realizar otras ocupaciones menores» (Monsalve Zanatti, 1998: 379). 
acompañar al cura doctrinero en el cuidado de los bienes muebles e inmuebles de la iglesia, de cuidar de la «fábrica» de las iglesias del curato (también en conjunto con el cura), de colaborar con las autoridades de fiestas y de cofradías religiosas en el cuidado de los bienes de las mismas; y finalmente, de cumplir de forma ejemplificadora los servicios, derechos y obligaciones religiosas ${ }^{21}$.

Por otro lado, el gobernador y cacique principal tiene el derecho en sus relaciones con el cura doctrinero, a ser tratado por él, como «señor de indios», de que llegado el caso de que deba ser amonestado, reprendido o castigado por el cura doctrinero por no haber cumplido con algunas de sus obligaciones para con él, que el rigor utilizado no sea excesivo y al parecer para este período que no se use la fuerza ${ }^{22}$.

También tienen los gobernadores y caciques indígenas el derecho a ser especialmente considerado en los honores y privilegios emanados de este rol de «señor de indios», como ser entierro especial en la iglesia sede del curato y llegado el caso de su cambio de lugar, de traslado de su cuerpo a la nueva construcción $^{23}$. También tiene el derecho a administrar más directamente que el cura los bienes de las cofradías y de las fiestas religiosas.

En suma, para fines de la colonia, el cura doctrinero y el gobernador y cacique actúan en conjunto en el gobierno de los feligreses, sin disputarse el gobierno sobre los indígenas y sin demasiados cuestionamiento a la legitimidad de la autoridad. Entrecruzándose en los ámbitos de ejercicio del poder: «fábrica» de las iglesias, construcción de los templos, administración de los bienes de la iglesia y de las cofradías, y gobierno de las cofradías y fiestas religiosas. Justamente este cruce da lugar a relaciones sociales que pueden ir de la armonía al conflicto: cuando se da la armonía en la relación se da la dominación del cura doctrinero, en cambio, cuando la relación se desarrolla en conflicto, la dominación del cura doctrinero es cuestionada.

Respecto de las otras dos autoridades indígenas, los alcaldes, si bien son colaboradores y llegado el caso reemplazantes directos del gobernador, no mantienen relaciones especiales con el cura doctrinero, salvo cuando el gobernador

21 Esto se había percibido y practicado desde los primero años de la conquista y colonización, cuando se consideraba a los curacas una garantía para el proceso de evangelización, pues según el segundo concilio limeño: «... la fe y la salvación de los indios pende de la voluntad y autoridad de sus caciques» (Monsalve Zanatti, 1998: 379).

${ }_{22}$ En este punto entran a jugar las cuestiones de disputa entre el fuero eclesiástico y civil, que para finales de la colonia parece favorecer al segundo respecto del primero (Saguier, 1997).

23 El entierro en la iglesia implica reconocer su rol de autoridad y las prácticas ya cotidianas del «sostenimiento de las iglesias» de los gobernadores y caciques indígenas. Evolución desde sus precolombinas «borracheras y gorduras», pasando por su seriedad en cuadros y escudos de armas grabados en las entradas de sus casas que «tienen por misión recordar la legitimidad de su función dentro de la nueva coyuntura colonial» (Saignes, 1987: 161).

Hispania Sacra, Missionalia hispanica, 58

117, enero-junio 2006, 355-381, ISSN: 0018-215-X 
no puede desempeñar las tareas que en conjunto desempeña con el cura doctrinero como la atención y el cuidado de los bienes muebles e inmuebles de las fiestas y cofradías religiosas.

En cuanto a los auxiliares específicos del cura doctrinero, podemos dividirlos en dos tipos: los auxiliares indígenas y los auxiliares no indígenas. Entre los primeros encontramos en este curato la figura del «ayudante», como colaborador directo tanto en los asuntos del evangelio como en los asuntos personales. En este caso se trata de dos ayudantes varones. También hay que comprender entre los ayudantes la figura de los «pongos», como los auxiliares de trabajo del cura doctrinero, que aunque por su rol deben prestarle servicios laborales «dentro» del respectivo curato, se los utiliza por lo general «fuera» del curato para el tráfico comercial del servicio religioso y del servicio personal del doctrinero. Los dos «pongos» deben ser mantenidos y pagados por el cura doctrinero, y si bien el control laboral de los mismos esta a cargo del mismo cura, la autoridad de ejercicio de castigos corre por cuenta del gobernador y cacique indígena.

Los auxiliares no indígenas son un segundo tipo de auxiliares de estos curas doctrineros. Se trata de parientes directos y otros españoles radicados en el curato. Dada las limitaciones que para el desarrollo de algunas actividades tiene el cura doctrinero (algunas permanentes y otras temporales), es usual que si tiene un pariente (usualmente un hermano) el cura doctrinero lo nombre como su apoderado para que lo represente en los negocios y asuntos que le incumben ${ }^{24}$. Respecto de los ayudantes españoles que no son parientes, en este curato figura a veces el cargo de «mayordomo», que se trata de un español a cargo de similares tareas que el pariente apoderado, pero que a diferencia de este, es rentado y mantenido por el cura doctrinero, junto a su familia si la tiene.

Un tercer actor social esta configurado por las autoridades de fiestas y cofradías religiosas. En este curato se trata de autoridades indígenas del tipo de mayordomos o alférez (ambas denominaciones se confunden), que están a cargo de la administración y fomento de los bienes muebles e inmuebles de las fiestas y de las cofradías, y de la organización y realización de sus celebraciones religiosas específicas.

Su competencia también abarca la administración de los bienes que las cofradías tienen dentro de las mismas iglesias o para el servicio religioso, como

\footnotetext{
${ }^{24}$ La primera gran limitación al ejercicio doctrinal de los curas doctrineros en estas regiones ya figuraba en la constitución décima de la primera parte del primer concilio de 1597 del Tucumán, y hacía alusión al «ausentismo de los curatos». Donde se determina que los curas de indios tengan un mes para hacer ausencias y las demás faltas se descuenten prorrata de sus estipendios (Toscano, 1906: 542). La otra limitación hace referencia a la prohibición más general respecto a que los curas doctrineros se desempeñen en el comercio, pues existía la percepción general de las autoridades de que «con excepción de unos pocos en todos los demás clérigos... hay muchos sediciosos, ignorantes y relajados, particularmente en comercios...» (Bruno, 1968: 460).
} 
puede ser la cera para la iluminación de la Iglesia durante los servicios religiosos de las fiestas y ceremonias de las cofradías (como son los servicios religiosos durante los aniversarios específicos de las cofradías, o las mismas por los cofrades). En este caso pueden entrar en conflicto con el cura doctrinero, pues la iglesia es su lugar específico. Pero donde su accionar es específico, aunque no exclusivo, es en la administración de los bienes de las cofradías y fiestas fuera de la iglesia. Se trata del ganado (vacas y ovejas), «sementeras" ${ }^{» 5}$ y tierras de las cofradías y fiestas. En esta tarea de la administración, cuidado, reproducción y aumento de estos bienes, puede o no contar con la participación directa del cura doctrinero, pero siempre su presencia se encuentra, pues el destino primario de los bienes de las cofradías y fiestas es para los servicios religiosos.

De nuevo las relaciones que establecen las autoridades indígenas de las cofradías y fiestas religiosas con el cura doctrinero, pueden ser armónicas o conflictivas, si se da la primera tenemos la dominación del cura, si se da la segunda tal dominación es cuestionada y los bienes muebles e inmuebles disputados a su control.

El cuarto actor se constituye por los encomenderos y las autoridades políticas con jurisdicción sobre el curato. En este curato y período, la figura del encomendero corresponde al marques del Valle de Tojo; que en sus relaciones con el cura doctrinero por el gobierno del curato, tiene un lugar secundario. Esto lo deduzco por distintas razones: primero y principal por su poca participación en la construcción y «fabrica» de las iglesias del curato, segundo por su limitada participación en la administración de los bienes de las cofradías y fiestas religiosas. Y finalmente, por su poca injerencia en la disposición de uso de mano de obra que el mismo cura doctrinero puede hacer de los «pongos», auxiliares indígenas directos y mano de obra de las mujeres y jóvenes del catecismo.

Sin embargo su rol se encuentra presente en cuanto a complementar el trabajo del cura doctrinero junto al gobernador indígena en la construcción de iglesias en el curato y en la fábrica de las mismas. De la misma manera el encomendero o su familia colaboran con el cura y son su apoyo en el manejo de las relaciones sociales al interior del curato, como puede ser la atención y cuidado y empleo de las personas que al cura le $\operatorname{sirven}^{26}$.

De una manera similar parece tener ese lugar de poder la autoridad política con jurisdicción sobre este curato de la Puna. Correspondiendo ese rol a comienzos del siglo XVIII, a los alcaldes del cabildo de Jujuy, y a finales de siglo al Subdelegado de la Puna. Tanto los alcaldes como el subdelegado in-

\footnotetext{
25 Las «sementeras» son cultivos en tierras de las comunidades indígenas, de las asociaciones religiosas o advocaciones, de cereales o de tubérculos.

26 «Causa criminal contra el cura de Cochinoca Manuel Benito Arias por desarreglo de vida y malas costumbres, Cochinoca, 6 de septiembre de 1803», AOJ, Caja 1, Legajo 12.

Hispania Sacra, Missionalia hispanica, 58

117, enero-junio 2006, 355-381, ISSN: 0018-215-X
} 
tervienen relativamente poco en los asuntos del gobierno religioso y político que el cura desempeña en este curato. También intervienen poco en las relaciones entre el cura y las autoridades indígenas, tanto de gobierno como de las cofradías o fiestas. Y no aparecen como una figura de poder cuando las relaciones se desarrollan armónicamente, y tampoco cuando se desarrollan conflictivamente. Sin embargo su poder se expresa en el marco de la actuación de los superiores eclesiásticos del cura doctrinero: el cura del rectoral o la visita episcopal.

\subsection{Las instituciones}

En cuanto a las instituciones construidas y de desarrollo de las relaciones sociales de poder entre todos estos actores, si bien ya las hemos mencionado como los lugares en donde se ejercen los derechos y desarrollan las obligaciones, requieren una mayor precisión acerca de su origen y funcionamiento.

El primer lugar lo ocupa una institución que desde los primeros años de la conquista y colonización permitió el desarrollo de las relaciones del poder entre los evangelizadores y los nuevos feligreses indígenas: las cofradías religiosas ${ }^{27}$, como una institución cristiana construida en las relaciones de poder entre los curas doctrineros, las autoridades y los indígenas de un curato rural y también urbano, que fueron aportadas a la relación por los doctrineros y reconocidas como válidas por los segundos ${ }^{28}$.

Es usual que en los curatos rurales de población mayoritaria indígena se desarrollaran las cofradías, una por lo menos en cada pueblo. Esto es lo que sucede en el curato de Cochinoca, donde funcionan por lo menos dos cofradías que cuentan con bienes adscriptos a una advocación y administrados por el cura doctrinero, las autoridades específicas de cofradías y a veces también por las autoridades civiles indígenas

En el primer juicio al cura Albornoz Ladrón de Guevara se menciona la existencia y funcionamiento de dos cofradías, aunque sin señalar su lugar de «asiento» (es decir su sede de funcionamiento): la de Nuestro Padre San José y la cofradía de Nuestra Señora (tal vez sea de la Asunción). Probablemente la primera localizada en la iglesia de Cochinoca y la segunda en la iglesia de Casabindo.

\footnotetext{
27 Una similar función le cupo en la evangelización de la Península Ibérica de los nuevos feligreses negros esclavos (Moreno Navarro, 1997).

28 Pues no sólo el aporte en condiciones de dominación colonial es lo que explica su difusión y desarrollo, sino sobretodo el reconocimiento y validez que le dan las autoridades y los indígenas. Sobre el tema de la difusión y desarrollo de las cofradías religiosas en el medio rural indígena hispanoamericano, puede verse: Bechtloff, 1996 y Celestino y Meyers, 1981.
} 
Aunque en el otro juicio al doctrinero Arias de 1803 no se mencionan directamente a las cofradías, por los libros de fábrica de las Iglesias de Casabindo y de Cochinoca, sabemos que funcionan en el curato en cuestión las siguientes asociaciones: en el pueblo de Casabindo Nuestra Señora de la Asunción, y al parecer, Nuestra Señora de la Asunción, Candelaria y Purificación en el pueblo de Cochinoca ${ }^{29}$.

Estas cofradías indígenas pueden considerarse como una institución económica religiosa, en las cuales participan el cura doctrinero, las autoridades indígenas y los indígenas, con el objetivo tripartito de sustraerse bienes y recursos, entre cada uno de estos tres actores.

Los bienes con los que cuenta estas instituciones son la sal que se recoge en las cercanas salinas, el ganado vacuno, caprino y ovejas, sementeras de trigo o maíz, plantaciones de papa, cera y velas y ornamentos y alhajas para el culto religioso. Y como recursos: el trabajo administrativo y financiero de las autoridades indígenas y del cura doctrinero, las tierras y estancias de ganado, el trabajo en las estancias y sementeras de los feligreses indígenas, la carne y derivados del ganado como quesos y vellones, las papas y pajas de las sementeras de cereales para consumo humano o del ganado, los elementos preciosos del culto religioso y el dinero ingresado como limosna o derivado de las ganancias, inversiones o préstamos de los otros recursos.

En el manejo de estos recursos de las cofradías, puede apreciarse las relaciones de poder entre los tres actores mencionados, y donde con más evidencia puede verse también el poder dominante del cura doctrinero, pues cuando predomina la armonía, el cura doctrinero es el actor principal en tal manejo de los recursos, destinados al culto y a la iglesia y también a su propio enriquecimiento. Dominio que también aparece cuando lo que predomina es el conflicto, ya que en este caso se puede cuestionar el control que el cura tiene de estos recursos, pero no se lo puede obviar en la dominación de la institución, principalmente por el carácter religioso de la misma.

Contrariamente a lo que sucede en otras cofradías religiosas bajo la jurisdicción de Jujuy, no tienen las del curato de Cochinoca un especial valor y uso para los procesos de identificación o reidentificación étnica, tal vez porque el medio es predominantemente indígena, o también porque existen otras instituciones que les permiten desarrollar estos procesos, como las numerosas y variadas tradiciones indígenas: Flechada (ceremonia y fiesta por la inauguración de un nuevo hogar), chucharuto o rutuchico (ceremonia y fiesta de trasquilar a los

\footnotetext{
29 «Inventarios hechos por los curas excusadores de los curatos de Casabindo y Cochinoca, de los bienes capellánicos de Nuestra Señora de la Asunción (patrona del pueblo de Casabindo), y de las cofradías de Nuestra Señora de la Asunción, Candelaria y Purificación. Correspondientes a los años 1798, 1799, 1801, 1803, 1804, 1813, 1826», Archivo Histórico de Jujuy, Caja 1, 1775-1826.
}

Hispania Sacra, Missionalia hispanica, 58

117, enero-junio 2006, 355-381, ISSN: 0018-215-X 
niños en su primer año de vida), señalada (fiesta y ceremonia de marcar el ganado en agosto, enero y febrero), entre otras (Olmedo Rivero, 1990; Poma de Ayala, 1989). Estaban reconocidas legalmente por la institución que se describe a continuación.

La otra institución muy desarrollada en esta parte de las Indias por el juego de relaciones de poder entre curas doctrineros, autoridades indígenas y feligreses indígenas, son los obvencionales: una utilidad fija o eventual que además del sueldo recibe cada cura doctrinero por lo servicios religiosos a su cargo que brinda o impone con una relativa y regional coacción extraeconómica a los feligreses a su cargo de evangelizar ${ }^{30}$.

Los obvencionales se institucionalizan cuando se impone como una «costumbre» en cada curato rural de indios, que las autoridades y los feligreses indígenas acuerden entregar bienes o dinero al cura doctrinero a cambio de que este sacralice todas sus prácticas tradicionales, por lo que le reconocen cierto status sagrado a una persona en principio ajena a dichas tradiciones religiosas. Y completan su institucionalización, cuando la Iglesia termina por aceptarlos al reglamentarlos. Lo que hace por diversos motivos: por las dificultades que en los curatos rurales de indios tienen los curas doctrineros para acceder al pago de su sínodo, por la disminución paulatina de los tributarios que les habilitaba otro pago sumado a su salario, por las relativamente difíciles condiciones de vida en estos parajes y pueblos ${ }^{31}$, y por los relativamente bajos salarios en estos curato. En suma, cuando advierte que de esa manera inserta mejor al cura doctrinero en los curatos de indios y a la vez descarga en otro el sostenimiento de su agente de poder.

Los obvencionales que se aplican en el siglo XVIII en este curato corresponden principalmente a una tradición no indígena que ya había sido institucionalizada en Europa gracias al desarrollo del purgatorio y del infierno: la muerte ${ }^{32}$. A pesar de ese carácter foráneo de esta tradición ya institucionalizada por el cristianismo, termina siendo reconocida por las sociedades indígenas, pues se adecua muy bien a sus tradiciones de culto a los ancestros (Salomón, 1990). Además la institucionalización en el nivel del reconocimiento social indígena nativo de los obvencionales, es posible porque se conforman como una «cos-

${ }^{30}$ El estudio de los obvencionales religiosos, como parte de la renta eclesiástica en los curatos rurales de indios, ha partido siempre de considerarlos como un componente más que importante en el esquema de dominación y explotación colonial (Acosta, 1982; Sala i Vila, 1993; Santamaría, 1983).

${ }^{31}$ El espacio geográfico que corresponde al curato de Cochinoca, se encuentra en lo que se conoce como la «Puna de Jujuy». Territorio frío, ventoso y de vegetación localizada lacustre a más de 3000 msnm. En el cual es común que los no nativos tuvieran que soportar el «apunamiento», forma coloquial y local con la que se conoce al conjunto de trastornos psíquicos, palpitaciones, exhalación de sudor y desmayos que en el Perú se conoce como «soroche».

32 El proceso de institucionalización occidental de la muerte (Aries, 2000) se dio a través del desarrollo del purgatorio (Le Goff) y del infierno (Minois, 1994). 
tumbre» que reconoce y le da legitimidad y legalidad a otras tradiciones indígenas locales, como el sirviñacu (a través del matrimonio) y el chucharuto o rutochico (a través del bautismo) ${ }^{33}$, para citar sólo dos ejemplos de extendida práctica y reconocimiento eclesiástico desde el período colonial hasta nuestros días ${ }^{34}$.

\section{CONCLUSIÓN}

Si el poder es la probabilidad de imponer la propia voluntad, dentro de una relación social, aun en contra de toda resistencia y cualquiera que sea el fundamento de esa probabilidad; y la dominación es la probabilidad de encontrar obediencia a un mandato de determinado contenidos entre personas dadas (Weber, 1998: 43), las relaciones entre los curas doctrineros, las autoridades indígenas y los feligreses indígenas corresponden a relaciones de poder, y la dominación del cura doctrinero es tal.

Esas relaciones de poder y el ejercicio mismo de la dominación de uno de esos actores, se desarrollan en el marco de un acuerdo de «expropiación colonial» en el cual cada uno de los actores tiene definidos y consensuados derechos y obligaciones. Regula a su vez la armonía y el conflicto que podría resultar del ejercicio del poder y del carácter dominante de uno de esos actores.

Sólo reconociendo la existencia de ese acuerdo, puede explicarse el dominio de los curas doctrineros en los curatos rurales de indios, y también de paso el desarrollo de instituciones y tradiciones institucionales que no son sincréticas, ni tampoco conjuntas y paralelas, sino que son originales y correspondientes a la religiosidad popular americana colonial. Hecho que en sí, explica de paso su importante desarrollo y notable vigencia histórica.

\footnotetext{
33 Esta institucionalización cristiana y estatal de las tradiciones indígenas, se desarrolla desde los primeros años de la conquista y colonización. Como figura en la Nueva Crónica y Buen Gobierno: «Las vírgenes acllas que sacan las cantoras y músicas y músicos y flauteros tamboreleros que le cantan al inga y a la señora coya, y a los señores capac apoconas, y a sus mujeres y para fiestas y pascuas, casamientos y bautismos, uarochicos, rutochicos, y fiestas del año y meses, todo lo que manda los Ingas» (Poma de Ayala, 1980: 300-302).

${ }^{34}$ La institucionalización de la costumbre que expresan los obvencionales, puede apreciarse con toda claridad también en los ciclos de fiestas campesinas andinas y el calendario litúrgico cristiano. Tal cual sucede en un paraje no tan lejano a Cochinoca como es Q'ero en Paucartambo y Quispicanchi en el actual Departamento de Cusco-Perú. Correspondiendo lo siguiente: «Todos los santos: primer esquilo; Pascua: cosecha de papas; San Juan: preparación de chacra; ...» (Muller, 1984: 168).

Hispania Sacra, Missionalia hispanica, 58

117, enero-junio 2006, 355-381, ISSN: 0018-215-X
} 


\section{FUENTES Y BIBLIOGRAFÍA}

\section{Fuentes}

- «Causa criminal contra el cura de Cochinoca Maestro Don Valentín Albornoz Ladrón de Guevara, año 1735». Archivo del Obispado de Jujuy, Caja 8, Legajo 15 (documento 653 y 656).

- «Causa criminal contra el cura de Cochinoca Manuel Benito Arias por desarreglo de vida y malas costumbres, 6 de septiembre de 1803». Archivo del Obispado de Jujuy, Caja 1, Legajo 12.

- «Juicio de cobro de las tazas de los indios de la encomienda de indios de Humhauca y Uquia por José Domínguez, Humahuaca-Jujuy, 1767». Archivo de Tribunales de Jujuy, Carpeta 44, Legajo 1469.

- «Inventarios hechos por los curas excusadores de los curatos de Casabindo y Cochinoca, de los bienes capellanicos de Nuestra Señora de la Asunción (patrona del pueblo de Casabindo), y de las cofradías de Nuestra Señora de la Asunción, Candelaria y Purificación. Correspondientes a los años 1798, 1799, 1801, 1803, 1804, 1813, 1826». Archivo Histórico de Jujuy, Caja $1,1775-1826$.

\section{Bibliografía}

Acosta, Antonio (1982): «Los clérigos doctrineros y la economía colonial (Lima, 1600-1630)», Allpanchis, 19, Cuzco, pp. 117-149.

ARIES, Philippe (2000): Morir en Occidente desde la Edad Media hasta la actualidad, Buenos Aires, Adriana Hidalgo editora.

Assadourian, Carlos Sempat (1983): El sistema de la Economía Colonial. El mercado interior. Regiones y espacio económico, México, Editorial Nueva Imagen.

Ayrolo Valentina (2000): «Representaciones sociales de los eclesiásticos cordobeses de principios del siglo XIX», Andes, 11, Salta, pp. 161-175.

- (2001): «Cura de Almas. Aproximación al clero secular de la diócesis de Córdoba del Tucumán, en la primera mitad del siglo XIX», Anuario del IEHS, Tandil, 16, pp. 421-443.

Bechtloff, Dagmar (1996): Las cofradías de Michoacán durante la época colonial. La religión y su relación política y económica en una sociedad intercultural, México, El Colegio de Michoacán. 
Brading, David A. (1994): Una iglesia asediada: el obispado de Michoacán, 1749-1810, México, Fondo de Cultura Económica.

BRUnO, Cayetano (1968): Historia de la Iglesia en la Argentina, tomos V, Buenos Aires, Editorial Don Bosco.

Caretta de Gaufin, Gabriela A. (1999): «Con el poder de la palabra y los hechos: el clero colonial de Salta entre 1770-1820», en Sara Mata de López (comp.), Persistencias y cambios: Salta y El Noroeste Argentino. 17701840, Rosario, Prohistoria \& Manuel Suárez editor, pp. 81-117.

CARMagnani, Marcello (1993): El regreso de los dioses. El proceso de reconstitución de la identidad étnica en Oaxaca. Siglos XVII y XVIII, México, Fondo de Cultura Económica.

Celestino, Olinda, y Meyers, Meyers (1981): Las cofradías en el Perú: región central, Frankfurt, Verlag Klaus Dieter Vervuert.

Cruz, Enrique (2001): «Oro, cera trigo y sal. Cofradías de indios en Jujuy», en Enrique Cruz (comp.), Iglesia, Misiones y Religiosidad colonial. Anuario del CEIC/1, Jujuy, Centro de Estudios Indígenas y Coloniales, Universidad Nacional de Jujuy, pp. 177-203.

- (2005): «Mujeres en la colonia. Dominación colonial, diferencias étnicas y de género en cofradías y fiestas religiosas en Jujuy, Río de la Plata», Anthropologica, Departamento de Ciencias Sociales, Pontificia Universidad Católica del Perú, año XXIII, 23, diciembre, pp. 127-150.

Diez HuRTAdo, Alejandro (1994): Fiestas y cofradías. Asociaciones religiosas e integración en la historia de la comunidad de Sechura (siglos XVII al $X X)$, Piura, CIPCA.

DuBy, Georges (1991): El amor en la Edad Media y otros ensayos, Buenos Aires, Alianza Universidad.

GARCíA AÑoveros, Jesús María (1990): «Visitas pastorales en la diócesis del Reino de Guatemala, 1752-1791», Hispania Sacra, año 42, julio-diciembre, Madrid.

GiBson, Charles (1986): Los aztecas bajo el dominio español, 1519-1810, México, Siglo XXI América Nuestra.

GRUZYNSKI, Serge (1995): La colonización de lo imaginario. Sociedades indígenas y occidentalización en el México español. Siglos XVI-XVIII, México, Fondo de Cultura Económica.

Harris, Olivia; LARSON, Brooke, y TANDETER, Enrique (comps.) (1987): La participación indígena en los mercados surandinos. Estrategias y reproducción social, Siglos XVI a XX, La Paz, CERES.

LAVALLÈ, Bernard (1982): «Las doctrinas de indios como núcleos de explotación colonial (siglos XVI y XVII)», Allpanchis, 19, Cusco, pp. 151-171. 
LE GofF, Jacques (1981): El nacimiento del purgatorio, Madrid, Taurus.

Madrazo, Guillermo B. (1982): Hacienda y Encomienda en los Andes. La Puna Argentina bajo el Marquesado de Tojo, siglos XVI-XIX, Buenos Aires, Fondo Editorial.

MAEDER, Ernesto (1984): La formación de la sociedad Argentina desde el siglo XVI hasta mediados del XVIII, Resistencia, Cuadernos docentes, $\mathrm{n}^{\circ}{ }^{\circ} 3$.

Millar CARVACHo, René (1997): «La Inquisición de Lima y el delito de solicitación», en Abelardo Levaggi (coord.) La Inquisición en Hispanoamérica. Estudios, Buenos Aires, Ediciones Ciudad Argentina, pp. 105-208.

MinoIs, Georges (1994): Historia de los Infiernos, Barcelona, Paidós.

Monsalve Zanatti, Martín (1998): «Miserables e idólatras: Los curacas frente a la administración eclesiástica», Actas del IV Congreso Internacional de Etnohistoria, Tomo 3, Pontificia Universidad Católica del Perú, Fondo Editorial, Lima, pp. 376-398.

Moreno Navarro, Isidoro (1997): La Antigua Hermandad de los Negros de Sevilla. Etnicidad, poder y sociedad en 600 años de historia, Sevilla, Universidad de Sevilla y Consejería de la Junta de Andalucía.

Morner, Magnus (1999): La Corona Española y los foráneos en los pueblos de indios de América, Madrid, AECI-Ediciones de Cultura Hispánica.

Moutoukias, Zacarías (1988): Contrabando y control colonial en el siglo XVII. Buenos Aires, el Atlántico y el espacio peruano, Buenos Aires, Centro Editor de América Latina.

MulLER, Thomas y Helga (1984): «Cosmovisión y celebración del mundo andino a través del ejemplo de la comunidad de Q'ero (Paucartambo)», Allpanchis, n. ${ }^{\circ} 23$, año XV, vol. XX, Cusco, pp. 161-176.

Olmedo Rivero, Jesús (1990): Puna, Zafra y Socavón. Homenaje al pueblo Colla, Madrid, Editorial Popular.

PARsons, Talcott (1991): «El concepto de poder político» en Classe, potere, status, vol. II, Status e repporti di potere, en Sociología del Poder, Buenos Aires, CEAL.

Poma de Ayala, Felipe Guaman (1980): Nueva Corónica y Buen Gobierno, tomo I, Caracas.

Pons Pons, Guillermo (1990): «Abancay en la época colonial: una doctrina peruana», Hispania Sacra, Madrid, vol. XLII, 86, pp. 593-633.

RAmos, Gabriela, y URbano, Henrique (comps.) (1993): Catolicismo y Extirpación de Idolatrías, siglos XVI-XVIII, Charcas, Chile, México, Perú», Cusco, $\mathrm{CBC}$ «Bartolomé de Las Casas». 
RAmos, Gabriela (comp.) (1994): «La venida del reino. Religión, evangelización y cultura en América, Siglos XVI-XX», Cuzco, Cuadernos para la historia de la Evangelización en América Latina, n. ${ }^{\circ} 12$.

SAGUIER, Eduardo (1997): «Los conflictos entre el clero y el estado en el mundo colonial. Las contradicciones entre el fuero eclesiástico y el patronato real», Anuario, Archivo y Biblioteca Nacionales de Bolivia, Sucre, pp. 201238.

SAIGNES, Thierry (1987): «De la borrachera al retrato: Los caciques andinos entre dos legitimidades (Charcas)», Revista Andina, año 5, número 1, julio Cusco, pp. 139-170.

- (1991): «Lobos y ovejas: formación y desarrollo de los pueblos y comunidades en el sur andino siglos XVI-XX», en Reproducción y transformación de las sociedades andinas siglos XVI-XX, Quito, Ed. Abya Yala/MLAL, pp. 91-136.

Sala I VILA, Nuria (1993): «Gobierno colonial, Iglesia y poder en Perú. 17841814», Revista Andina, Cusco, 1, pp. 133-161.

- (1994): «Algunas reflexiones sobre el papel jugado por la iglesia y el bajo clero en las parroquias de indios en Perú (1784-1812)», Gabriela Ramos (comp.), Religión, evangelización y cultura en América, Siglos XVI-XX, Lima: CERA «Bartolomé de Las Casas», pp. 339-362.

SALOMÓN, Frank (1990): «Culto a los ancestros y resistencia frente al Estado en Arequipa entre los años 1748 y 1754», en Steve J. Stern (comp.), Resistencia, rebelión y conciencia campesina en los Andes, siglos XVIII al XX, Lima, IEP, pp. 148-163.

SÁnchez Matamoros, Alonso (2004): «San Antonio de Omaguaca, siglo XVIII», en Un tesoro en vasijas de Barro. Virgenes y profetas de Humahuaca, Humahuaca, Prelatura de Humahuaca, Edición en CD.

SANTAMARÍA, Daniel J. (1983): «Iglesia y economía campesina en el alto Perú, siglo XVIII», Ocasional pappers seris, Miami.

- (1999): «Mercaderes, tenderos y prestamistas. La mercantilización de la economía jujeña (1690-1730)», Anuario del IEHS, n. ${ }^{\circ}$ 14, Tandil, pp. 437469.

WEBER, Max (1998): Economía y Sociedad. Esbozo de sociología comprensiva, México, Fondo de Cultura Económica. 
ANEXo

MAPA 1: JUJUY EN LA CIRCULACIÓN MERCANTIL REGIONAL

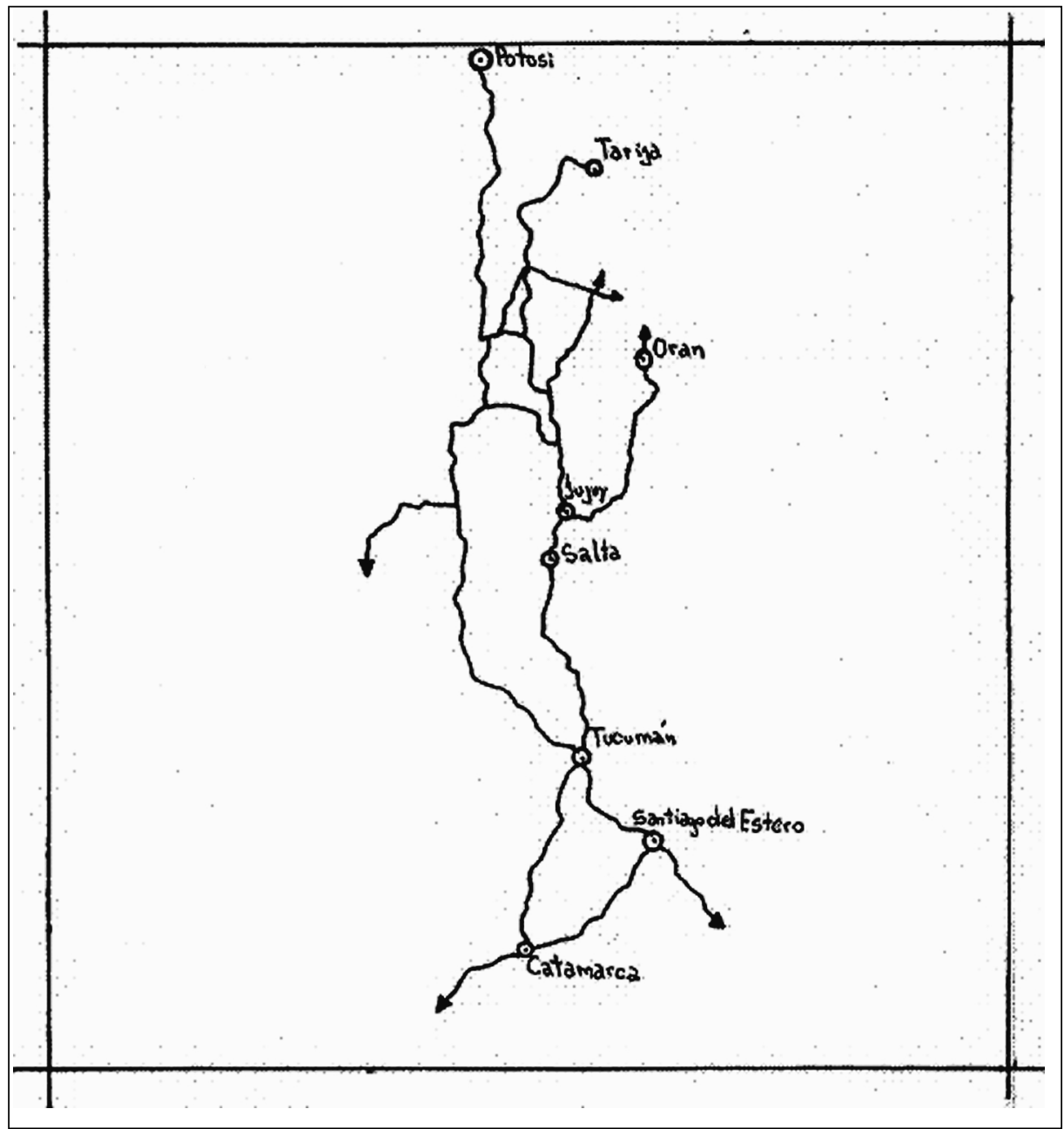

Hispania Sacra, Missionalia hispanica, 58 117, enero-junio 2006, 355-381, ISSN: 0018-215-X 


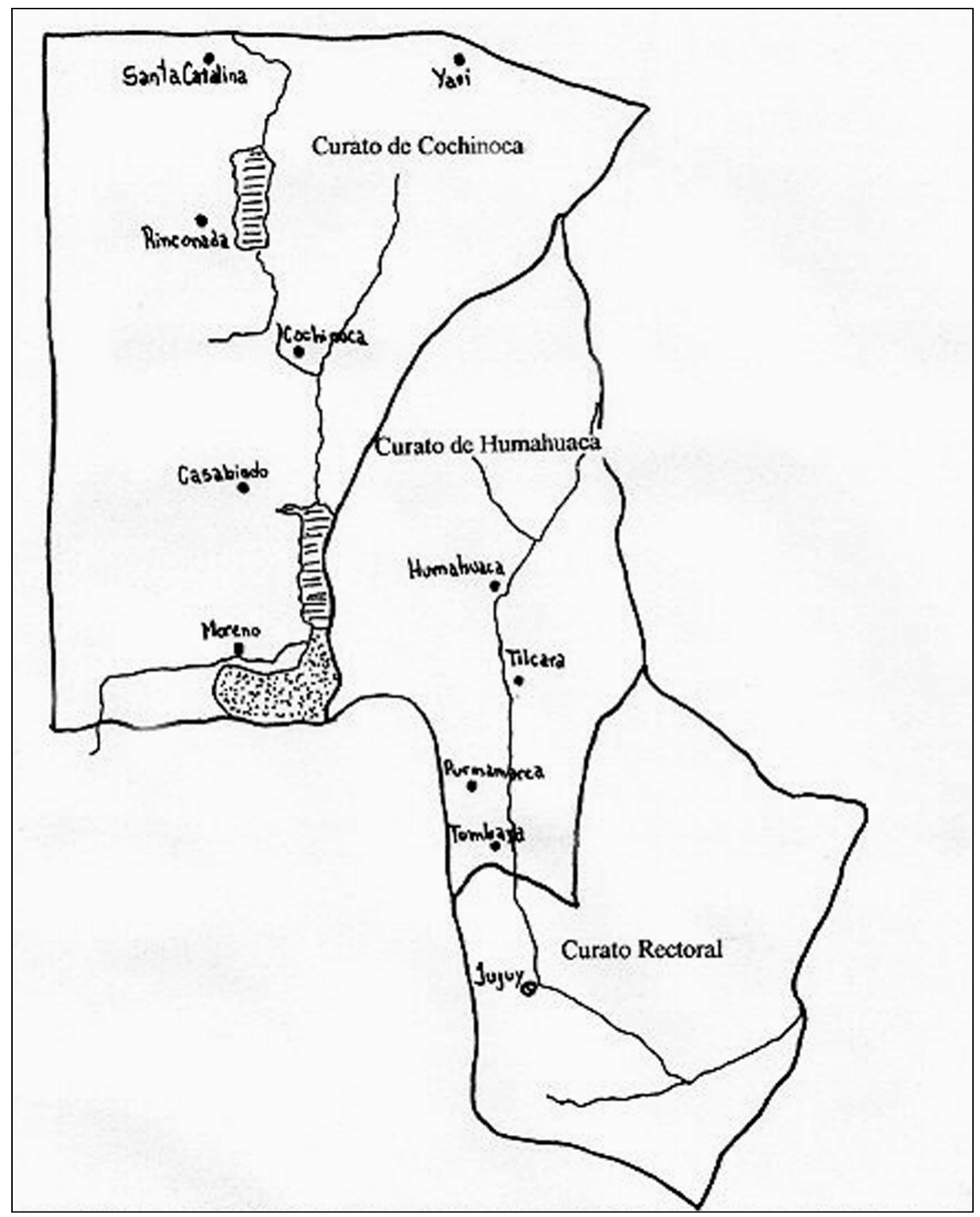

Hispania Sacra, Missionalia hispanica, 58 
Mapa 2: CuRATOS DE JuJuY: 1735-1803 (continuación)

1803

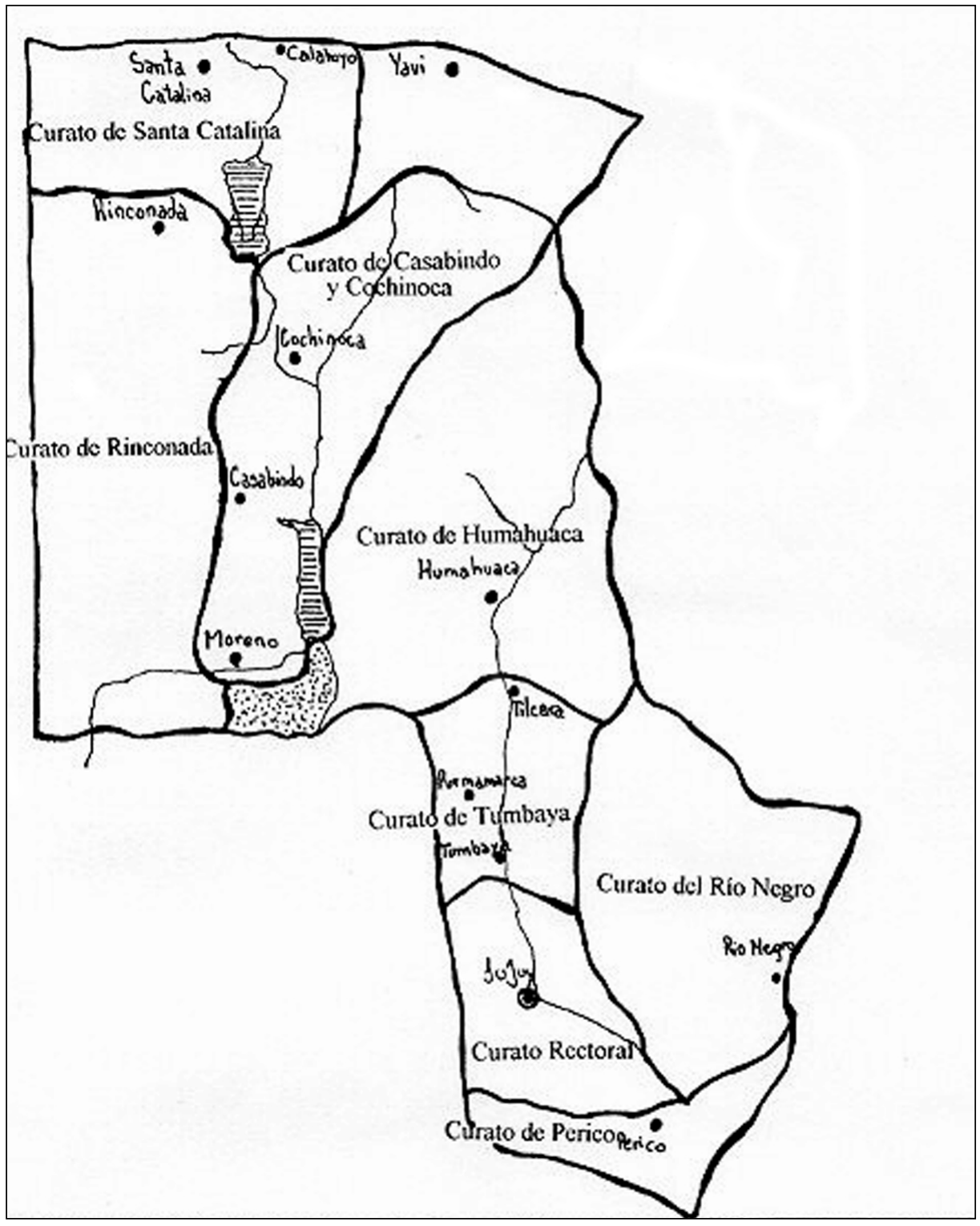

Hispania Sacra, Missionalia hispanica, 58 117, enero-junio 2006, 355-381, ISSN: 0018-215-X 